\title{
Public selection and financing of R\&D cooperative projects: Credit versus subsidy funding
}

\author{
Lluís Santamaría $^{\mathrm{a}, 1}$, Andrés Barge-Gil ${ }^{\mathrm{b}, 2}$, Aurelia Modrego ${ }^{\mathrm{c}, *}$ \\ a Universidad Carlos III de Madrid, Department of Business Administration, Calle Madrid, 126, Getafe (Madrid) 28903, Spain \\ ${ }^{\mathrm{b}}$ Universidad Complutense de Madrid, Departamento de Fundamentos de Análisis Económico II, N119, Facultad de Ciencias Económicas y Empresariales, \\ Pozuelo de Alarcón (Madrid) 28223, Spain \\ ' Universidad Carlos III de Madrid, Laboratory for Analysis and Assessment of Technical Change, Calle Madrid, 126, Getafe (Madrid) 28903, Spain
}

\section{A R T I C L E I N F O}

Article history:

Received 15 November 2007

Received in revised form

15 December 2009

Accepted 20 January 2010

Available online 12 February 2010

\section{JEL classification:}

$\mathrm{H} 23$

$\mathrm{H} 43$

H53

Keywords:

Public Funding

R\&D Cooperation

Project selection

Credit

Subsidy

\begin{abstract}
A B S T R A C T
In this article we develop an analytical model of the selection process for R\&D cooperative projects, to study the factors that motivate public project selection and corresponding funding, using two different financial instruments: subsidies and credits. For this purpose, we propose a three stage empirical strategy to analyse the differential individual effects of several factors on the decisions taken by the public agency. This analysis is based on project level data from cooperative R\&D project calls under the Spanish PROFIT initiative, for the period 2000-2003. The main results show that the public agency uses the two financial instruments to address different objectives. First, some projects close to the market are well supported through credits, while basic research projects receive only selective support in the form of subsidies. Second, there is significant diversity in the selection and funding of technological areas. Third, regarding the explicit goal of fostering cooperation, the public agency selectively favours partnerships with universities and technology institutes through the award of subsidies. However, there seems to be less incentive for large consortia. Fourth, there are significant regional differences among financed projects and, also, our data show sharp yearly fluctuations.
\end{abstract}

\section{Introduction}

The importance of research and development $(\mathrm{R} \& \mathrm{D})$ as one of the main contributors to sustainable growth in highly industrialized economies is undisputed among economists, and especially in the context of the modern knowledge based economies. This means that government support for R\&D activities is widely accepted, in contrast to public support in the areas of investment, production or commercial protection (García-Quevedo, 2004; Giebe et al., 2006; Heijs, 2003). The broad consensus on the value of public support for $R \& D$ is rooted in the existence of market failures (Arrow, 1962) which create a gap between the private and social benefits deriving from R\&D activities. This gap implies that private resources dedicated to R\&D activities will always be below the social optimum (Klette et al., 2000). As consequence, since the mid 1980s,

\footnotetext{
* Corresponding author. Tel.: +3491624 9302; fax: +34916249517.

E-mail addresses: Isantama@emp.uc3m.es (L. Santamaría), abarge@ccee.ucm.es (A. Barge-Gil), modrego@eco.uc3m.es (A. Modrego).

${ }^{1}$ Tel.: +34 91624 8643; fax: +34 916249607

2 Tel: +34 91394 2355; fax: +34913942591.
}

public expenditure oriented to supporting industrial R\&D accounts for some 30 per cent of total R\&D expenditure in the OECD area (OECD, 2001), and as much as 36 per cent in the European Union (EU) countries. In the case of Spain the share of public funding of $R \& D$ activities in the private sector is close to 40 per cent (OECD, 2001).

Technological agreements can be another solution to some of the failures in technology markets, especially in the case of appropriability (Cassiman, 2000) and uncertainty (Smith, 1991). Some general trends (i.e. new scientific challenges more capitalintensive or shorter life cycles of products) make the individual actions of firms difficult, and increase the relevance of cooperation in the innovation process (Heijs, 2005a). Cooperative agreements boost firm innovativeness by their effective combining of partners' resources and exploitation of complementarities (Kogut, 1988; Das and Teng, 2000; Hagedoorn et al., 2000). Moreover, cooperation generates externalities for society as a whole conceptualized in the notion of collective learning (Heijs, 2005a).

In spite of the above mentioned benefits, there are several barriers and transaction costs, especially those related to coordinating, managing and controlling the activities of the different parties involved, which could inhibit organizations' engagement in tech- 
nological cooperation (Becker and Dietz, 2004). Thus, considering the impact of cooperation on private profits and social benefits, the greatest challenge for public policy is to find mechanisms that promote cooperation, usually the provision of funding (Bozeman, 2000). To this end, various support programmes have been implemented in the US, Japan and the EU to encourage private R\&D efforts and research partnerships between private firms and public research organizations (PROs). Some examples are the Advanced Technology Program in the US and the successive European Framework Programmes.

Many questions of political interest are suggested by the previous arguments and are a good motivation for this paper. According to Fölster (1995), public funding for cooperative R\&D is an effective tool for encouraging private research and increasing cooperation in line with social incentives. However, it should be remembered that research funding is an uncertain business, and the outputs of R\&D are not only equally uncertain, but also skewed (Molas-Gallart and Salter, 2002). Under these conditions, one of the main problems for research policy is how to distribute research funds to satisfy multiple objectives.

According to Bozeman and Rogers (2001), public R\&D management tends to be discrete and ad hoc, focusing on generating maximum output through individual projects. In some cases, public agencies use public funding mechanisms to attract firms to a particular location (country or region), or to encourage technological upgrading in firms of particular importance (in terms of employment, for instance) to the country or region. In this case, the supply and distribution of funds among selected R\&D projects and firms is trying to fulfil a variety of goals (Blanes and Busom, 2004). However, if the selection criteria are not well defined, many public programmes will fail to reach their targeted populations (Blanes and Busom, 2004; Heijs, 2005b). This highlights the importance of clearly setting out the public sector evaluation criteria and procedures for selecting and funding R\&D projects.

The main contribution of this paper is in providing an analysis of the selection process for cooperative R\&D projects by studying some of the factors that jointly influence project selection and funding amounts, and by showing how different financial instruments are used. Although there is a large tradition in the study of public support schemes for R\&D activities, ${ }^{3}$ to our knowledge, this is one of the few attempts to analyse the effects of simultaneous utilization by public agencies of subsidies and credits ${ }^{4}$ for funding projects. We look particularly at the selection process adopted by a Spanish public agency in charge of funding cooperative R\&D projects using these two financial mechanisms: subsidies and credits. In doing so, the purpose of the study is threefold: a) to identify some of the factors influencing project selection and resources allocation; b) to analyse the extent to which the results of the public agency's decisions comply with the main goals established by the funding programme; and c) to show how the two financial instruments-subsidies and credits - are used. To carry out this work we use project level data from a Spanish innovation support initiative, the PROFIT ${ }^{5}$ Programme, for 2000-2003. The sample consists of 2,790 project proposals, with an acceptance rate of about $45 \%$.

PROFIT is the Spanish government's main technical innovation support programme, designed to foster innovation in all sectors (industry, government and research) and technological areas. It

\footnotetext{
3 This is particularly important in Spain. See, e.g. Molero and Buesa, 1995; Acosta and Modrego, 2001; Heijs, 2001, 2003, 2005b; Blanes and Busom, 2004; Herrera and Heijs, 2007.

${ }^{4}$ Huergo and Trenado (2008) analyse Spanish public aid for R\&D projects from the public agency point of view, although they were not able simultaneously to study subsidies and credits: the programme they analyse is focused on credits.

5 PROFIT: 'Programa de Fomento de la Innovación Tecnológica' (Programme of Promotion of Technological Innovation).
}

should be noted that the period 2000-2003 was the first period when financial support was awarded explicitly to both individual and cooperative projects, implementing measures designed to encourage the participation of one specific type of research organization, the technology institute (TI). The PROFIT data base contains information on project inputs, expected outputs, research partners, technological area or programme, geographical area of applicant organizations and the year of call, which allows us to explore some factors underlying the public selection of R\&D cooperative projects and the application of subsidies and credits. In this sense, this study could be considered as complementing studies focused on the factors that lead a firm to participate in R\&D subsidy programmes (Acosta and Modrego, 2001; Blanes and Busom, 2004).

The paper is organized as follows. In Section 2, we review the existing literature, describe the PROFIT programme and, based on this, develop arguments and conjectures about the public selection of $R \& D$ cooperative projects. We describe the data, the variables and the empirical strategy in Section 3, and discuss the results in Section 4 . Section 5 presents the conclusions.

\section{Public selection and funding of cooperative R\&D projects}

The main trend in innovation policies during the last two decades is characterized by what is termed the 'cooperative paradigm', or the fostering of cooperation among sectors - industry, government and research - and among rival or vertically related firms (Bozeman, 2000). Public support for cooperation would seem to be justified if we take account of Von Hippel's (1988) arguments about the relevance of technological alliances and networks as the main sources of innovation. In addition, according to Duysters et al. (1999), alliances have shifted from being a somewhat peripheral aspect to become a cornerstone of the firm's technological strategy. Therefore, public administrations, conscious of the potential of technological agreements, do not hesitate to give financial support to the setting up of R\&D collaborations, through a range of R\&D funding programmes, many explicitly focused on fostering R\&D cooperation (Geroski, 1992; Martin, 1996).

\subsection{Public selection of RED projects}

Several studies have focused on evaluating the effectiveness of R\&D programmes (Meyer-Krahmer and Montigny, 1989; Ormala, 1989; Roessner, 1989) and their influence on private R\&D efforts (David et al., 2000; Klette et al., 2000). However, few works have examined the criteria used by government evaluators to select projects (Hsu et al., 2003; Lee and Om, 1996, 1997). Knowledge of these criteria is crucial for two reasons: first they reflect the real objectives of policy makers and, second they determine the characteristics of those projects that are actually implemented or developed and, consequently, the results obtained. Also, they can affect not only responses to future calls, but also the definition and content of project proposals.

In the context of R\&D project selection in a private firm, top management is obliged to resolve the crucial problem of adopting a proper selection method to identify those projects that fit with organizational goals (Lee and Om, 1997). This has led to the hundreds of methods and techniques available in the literature for R\&D project selection (Hsu et al., 2003). These approaches tend to be either qualitative or quantitative, and range from unstructured peer review to sophisticated mathematical programming (Henriksen and Traynor, 1999; Hsu et al., 2003). In the process of R\&D project selection, whatever method is used, one of the most important steps is to calculate technical and market risks (Taggart and Blaxter, 1992), a rather infrequent practice in the public sector (Bozeman and Rogers, 2001, p. 414). So why is it so difficult for the 
public sector to apply a systematic and strategic R\&D project management bearing in mind the magnitude of its government funding decisions?

One plausible explanation is offered by Hsu et al. (2003) who point to two major differences between public and private sponsored projects. Firstly, public funding of R\&D projects generally involves strategic and long-term investment, thus, conventional financial justification approaches are probably inadequate. Secondly, the allocation of R\&D resources in the public sector may be influenced by political factors and a variety of interest groups. Similarly, Bozeman and Rogers (2001) indicate that systematic and strategic R\&D programme management is difficult to accomplish in the public sector for several reasons: i) government funded R\&D generally does not have commercial products and processes as its short term objective; ii) public agencies are subject to annual budget cycles; iii) the various goals of different government agencies often conflict; and iv) time horizons are different.

The arguments in some of the existing studies lead us to conclude that selecting R\&D projects for public evaluation is a difficult task for several reasons related to expected externalities, multiple objectives and multiple stakeholders, some of whom may have conflicting objectives and preferences. These factors determine total budget allocated to R\&D programmes, distribution across industries, ranking criteria or screening rules applied in the selection of projects and firms, and the funding awarded to individual firms (Blanes and Busom, 2004, p. 1465). The question that arises, therefore, is how do these factors affect the selection process?

As a first step towards answering this question, and given that the purpose of the paper is to study the factors that affect project selection and funding within the Spanish PROFIT programme, we provide a careful description of the programme. This is followed by a rehearsal of some expectations related to the public selection of R\&D cooperative projects, based on PROFIT goals and its explicit selection rules, as well as the theoretical arguments.

\section{2. $R E \mathcal{E}$ cooperative projects: The case of the PROFIT programme}

PROFIT is the major technical support programme of the Spanish government, integrated within the National Plan of Scientific, Research, Development and Technological Innovation. It was first run in 2000, as a continuation of previous innovation programmes (Castro, 2001) and was distinguished by two new features: i) that it provided funding for both individual and cooperative projects; and ii) that two funding mechanisms (credits and subsidies) were implemented simultaneously. By providing public funding, it was seen as an instrument that would mobilize firms and other organizations (especially universities and TIs) to undertake (more) R\&D activities.

The main objectives of the PROFIT initiative were to: i) increase the application of knowledge and the incorporation of ideas in the manufacturing process; ii) strengthen rapid growth industries and markets; iii) boost the competitiveness of the manufacturing sector by developing and incorporating new technologies; and iv) promote the integration and cooperation of the different agents involved in the science-technology-firm system.

PROFIT covered several knowledge fields which represent priorities for Spanish technology policy. These included technological areas, such as Biotechnology, Industrial Design and Production, Materials, Chemical Products and Processes, Natural Resources, Agro-foods, Information and Communication Technologies, Biomedicine and Socioeconomics, and sectoral areas such as Aeronautics, Automobiles, Energy, Environment, Information Society and, Transport and Territorial Arrangements. In general, criteria for eligibility and selection were uniform across these different knowledge fields.
PROFIT enabled support for a wide typology of projects: i) industrial research projects, oriented mainly towards basic research; ii) pre-industry research technical viability studies; iii) pre-competitive development projects to produce results useful for industry; iv) technological demonstration projects to develop pilot projects or demonstrate the results of Pre-Development projects; ${ }^{6}$ v) special actions oriented to diffusion activities ${ }^{7}$ (such as conferences and seminars) and technology transfer; and vi) actions to promote cooperation and participation in international $R \& D$ programmes (i.e. EUREKA, IBEROEKA and the EU Framework Programmes).

The financial instruments included interest free credits, and subsidies. While generally the procedure was to assign either a credit or a subsidy, in some cases, and for some projects, the award of both types of support was possible. However, there was a cap on project funding - across all types of regions and all knowledge fields. This cap was different for credits and subsidies. While a subsidy could finance $100 \%$ of the project budget, a credit could represent only $75 \%$.

The eligibility and selection rules applying to PROFIT knowledge fields are related to: i) adequacy of PROFIT goals; ii) degree of innovativeness and technological development of a project; iii) high quality as well as technical, economical and financial viability; iv) applicability of project results; v) promotion of cooperation; and vi) promotion of R\&D activity. Although some of these criteria (i.e. promotion of cooperation) are clearly linked to the PROFIT goals, the selection rules require a global valuation of each project. Thus, for instance, the criteria 'adequacy of goals' implies analysis of project coherence with some (but not necessarily all) of the PROFIT goals. In other cases, such as the viability of the project, the key point is not the fit of the project with PROFIT goals, but its possibility of success. In any case, the PROFIT goals are more or less explicit in the rules for eligibility and selection. The main question then, given these goals and selection rules, is which factors are the most critical in the process of selection and funding of cooperative projects within the PROFIT programme.

\subsection{Project selection by the PROFIT programme: some expectations}

Given the characteristics of the PROFIT programme, the public agency is required to make three decisions in the course of the selection process. First, the decision to accept or reject a project; second, whether to assign a subsidy, a credit, or both to the accepted projects; and third, to decide how much of the project budget to finance. Analysis of the three decisions sheds some light on the public agency's behaviour and particularly in relation to decisions about the degree of support to different projects. The first decision is cut and dried, and either includes or excludes projects from further consideration. The second and third decisions entail some discrimination among the accepted projects in terms of type and amount of finance provided. Analysis of the second decision enables an examination of the different factors influencing the type of funding assigned. Analysis of the third decision allows us to show how these characteristics influence the amount of the project budget to be financed. Given that two different financial instruments are implemented simultaneously in the PROFIT initiative, it is reasonable to expect that they address different objectives.

With these three decisions in mind, we discuss our expectations related to the public agency's selection and funding processes

\footnotetext{
${ }^{6}$ Their final goals were development of a prototype, validation by the users, and international projections.

7 Essentially, diffusion of firm R\&D results and different public policy instruments to support firms' innovation processes.
} 
related to $R \& D$ projects, which are far from straightforward. In all three decision phases, the public agency has multiple objectives and selection criteria, some of which are contradictory. In the specific context of the PROFIT programme, the main goals are explicated in the public calls for proposals and in the selection criteria. Combining these with the theoretical arguments, we can make various expectations about the selection of projects for funding within this programme. We develop our expectations about project characteristics and their fit with the abovementioned PROFIT goals. We also take account of certain other factors not explicitly related to PROFIT goals, which may exert an influence along the different stages of the PROFIT programme selection process.

\subsubsection{Application of knowledge and ideas}

The main reason for providing public funding for $R \& D$ is market failure; that is, the objective of the public agencies is to fund R\&D projects that otherwise would not be conducted because of externality problems or failures in the capital market. These projects are usually those more distant from the market. However, as already mentioned, one of the aims of the PROFIT initiative is to increase the application of knowledge and the incorporation of ideas, within the manufacturing process, and the applicability of project results is one of the selection criteria. This implies that although PROFIT provides funding to a wide typology of R\&D projects, those closer to achieving an applicable result (i.e. pre-competitive development, viability studies, demonstration, diffusion projects) are more likely to or will receive more support than those oriented towards basic research. ${ }^{8}$ Other selection criteria relate to the degree of innovativeness and technological development of a project and to its promotion of R\&D activity. These criteria suggest a positive attitude towards projects with higher expected outputs in terms of R\&D expenses.

\subsubsection{Industries and technological areas}

According to Blanes and Busom (2004), public agencies may use financial support for R\&D to achieve two important goals: i) to foster national champions; and ii) to encourage the technological upgrading of firms in declining or traditional industries. In the first case, the idea would be to fund those $R \& D$ projects that are more likely to achieve technological and/or commercial success. In the second case, the objective is to increase the chances of firm survival. Such reasoning implies that agency goals, or the combinations of goals, will vary across industries.

Concerning PROFIT goals, two are informative about the orientation to specific industries. One is aimed at supporting rapid growth industries and markets. This implies we could expect funding to be directed especially to projects in sectors and knowledge areas that are both new and technologically more advanced (i.e. Aeronautics, Biomedicine) Another of PROFIT's aims is to boost the competitiveness of the manufacturing sector by developing and incorporating new technologies in industry. This is a horizontal goal, across all industries, so would fit with the idea of technological upgrading of firms in both mature and more technologically advanced industries. Taken together, these two main aims would suggests that there are no knowledge areas that are discarded a priori, but that some, that is, the more technology advanced, will receive more favourable consideration.

\footnotetext{
8 In fact, within the Spanish Government's 'R\&D Plan 2000-2003' there was a funding programme oriented specifically to basic research called 'Promoción General del Conocimiento' (General Promotion of Knowledge), which was not included under the PROFIT programme.
}

\subsubsection{Cooperation}

Technological cooperation is a mechanism used to solve some forms of market failure (i.e. appropriability and uncertainty) and to boost firm innovativeness (i.e. by combining resources and exploiting complementarities). In spite of the problems related to the management of alliances (i.e. transaction costs), their positive impact has motivated governments to design public policies that promote cooperation. In this context, PROFIT was aimed at the promotion of cooperation among the different agents in the system: science and technology organizations, academia, and firms. This aim is made explicit in the main objectives and selection criteria of PROFIT. Also, as discussed in the description of the PROFIT call, the initiative is aimed especially at promoting collaboration between firms and PROs (i.e. universities and TIs).

Since PROFIT encourages firms' to exploit the knowledge embedded in PROs, we would expect the process of selection to be influenced by the degree of this cooperation. More precisely, we would expect a more positive approach to those projects with a university or a TI partner. In addition, given the objective to promote cooperation, we would expect the number of entities involved in a project to be important in the public evaluation of R\&D cooperative projects. Consistent with this, we would also expect a positive attitude of the public agency towards those projects oriented to promoting and preparing international R\&D partnerships (another category within the PROFIT typology of projects).

\subsubsection{Factors additional to PROFIT goals}

In addition to the arguments related to PROFIT goals, public assignment of funds may be conditional on other factors, such as year of the call, applicant's region, and project size. Bozeman and Rogers (2001) highlight that public agencies are subject to annual budget cycles and, moreover, that distribution of funds is conditioned by demand. In this context, Shapira et al. (1995) highlight the importance of stable public programmes in order to induce trust and confidence in the target organizations. Thus, in order to control for the influence of annual budgetary cycles, it is necessary to check for yearly differences in the probability of an R\&D cooperative project being accepted and financed.

The Spanish region of the applicant organization is another factor that may influence funding. It is possible that regional differences in the selection of projects are related to the peculiarities of regional industrial systems (i.e. firm characteristics), which may influence the level of support given to firms from different regions. It is possible also that politics plays a part in regional differences. The impact of political criteria is difficult to capture; it is likely also that politics will enter other areas of the decision making over selection and funding. However, it is important to control for regional differences.

Finally, we would expect project size (Heijs, 2005b) to be significant in the selection process. Acosta and Modrego (2001) find that government evaluators favour large projects. Thus, we would conjecture that the amount of inputs (measured by project budget and number of project hours) would be important factors in project selection.

Table 1 summarizes the potential factors affecting the process of project selection in the PROFIT programme, and the empirical expectations.

\section{Data issues}

\subsection{A brief overview of the data}

The information on the PROFIT initiative used in this study comes from the Science and Technology Office administrative database, which includes both accepted and rejected projects. This 
Table 1

Potential factors affecting public selection and funding of R\&D cooperative projects.

\begin{tabular}{|c|c|c|}
\hline PROFIT goal & Theoretical rational & Empirical expectation \\
\hline \multirow{2}{*}{$\begin{array}{l}\text { Increase application of knowledge and incorporation } \\
\text { of ideas in the manufacturing process }\end{array}$} & Market failures & Preference for projects: \\
\hline & & $\begin{array}{l}\text { - near to the market (pre-competitive development, } \\
\text { viability studies, demonstration, or diffusion) rather } \\
\text { than those focused on basic research } \\
\text { - with higher amount of expected R\&D }\end{array}$ \\
\hline Strengthen rapid growth industries and markets & Industries and technological areas & $\begin{array}{l}\text { Preference for projects: } \\
\quad \text { - located in sectors and knowledge areas } \\
\text { technologically more advanced (i.e. Aeronautics or } \\
\text { Biomedicine) }\end{array}$ \\
\hline \multicolumn{3}{|l|}{$\begin{array}{l}\text { Boost the competitiveness of the manufacturing sector } \\
\text { by developing and incorporating new technologies }\end{array}$} \\
\hline \multirow{3}{*}{$\begin{array}{l}\text { Promote the integration and cooperation of the } \\
\text { different agents involved in the } \\
\text { science-technology-firm system }\end{array}$} & Cooperation & Preference for projects: \\
\hline & & $\begin{array}{l}\text { - with the participation of universities and/or TI } \\
\text { - with a high number of partners } \\
\text { - with international R\&D cooperations }\end{array}$ \\
\hline & Factors additional to PROFIT goals & $\begin{array}{l}\text { Annual, regional and project size differences in terms } \\
\text { of project support }\end{array}$ \\
\hline
\end{tabular}

Source: Own elaboration.

Table 2

Overview of projects.

\begin{tabular}{|c|c|c|c|c|c|}
\hline & \multicolumn{4}{|l|}{ Year of the call } & \multirow[t]{2}{*}{ Total period $2000-2003$} \\
\hline & 2000 & 2001 & 2002 & 2003 & \\
\hline Number of project proposals & 501 & 749 & 784 & 756 & 2790 \\
\hline Number (and percentage) a of accepted projects & $250(49.90 \%)$ & $321(42.86 \%)$ & $315(40.18 \%)$ & $383(50.66 \%)$ & $1269(45.48 \%)$ \\
\hline $\begin{array}{l}\text { Number (and percentage) }{ }^{\mathrm{a}} \text { of projects with } \\
\text { subsidies }\end{array}$ & $208(41.52 \%)$ & $244(32.58 \%)$ & $248(31.63 \%)$ & $307(40.61 \%)$ & $1007(36.09 \%)$ \\
\hline Average subsidy per project $(€)$ & 206,162 & 78,768 & 66,481 & 85,435 & 103,034 \\
\hline $\begin{array}{l}\text { Number (and percentage) }{ }^{\mathrm{a}} \text { of projects with } \\
\text { credits }\end{array}$ & $62(12.38 \%)$ & $110(14.69 \%)$ & $103(13.14 \%)$ & $109(14.42 \%)$ & $384(13.76 \%)$ \\
\hline Average credit per project & 455,153 & 162,464 & 132,477 & 183,177 & 220,135 \\
\hline $\begin{array}{l}\text { Number (and percentage) }{ }^{\mathrm{b}} \text { of projects with } \\
\text { subsidy only }\end{array}$ & $188(75.20 \%)$ & $211(65.73 \%)$ & $212(67.30 \%)$ & $274(71.54 \%)$ & $885(69.67 \%)$ \\
\hline $\begin{array}{l}\text { Number (and percentage) }{ }^{\mathrm{b}} \text { of projects with a } \\
\text { credit only }\end{array}$ & $42(16.80 \%)$ & $77(23.99 \%)$ & $67(21.27 \%)$ & $76(19.84 \%)$ & $262(20.56 \%)$ \\
\hline $\begin{array}{l}\text { Number (and percentage })^{\mathrm{b}} \text { of projects with } \\
\text { both a subsidy and a credit }\end{array}$ & $20(8.00 \%)$ & $33(10.28 \%)$ & $36(11.43 \%)$ & $33(8.62 \%)$ & $122(9.77 \%)$ \\
\hline
\end{tabular}

database provides information related to the decisions of the public agency (to accept or reject the project, type of funding assigned, and percentage of the project to be financed by subsidies and/or credits), internal characteristics of the project (planned work hours, project budget, expected outputs, and type of research), technological and sectoral areas of the project, number of organizations involved, collaboration with PROs (universities and/or TIs), the Spanish region of each partner, and year of project proposal. Lack of access to all project data and information, such as characteristics of applicant organizations and the public agency's perception of project quality, means that these variables could not be included in our analysis, ${ }^{9}$ and is a shortcoming of this work. Nevertheless, we believe that our study is both interesting and novel in exploiting the public agency's administrative database, which gives access to the kind of information usually not available for academic analysis. This allows us to apply econometric models that provide an alternative view to studies that focus on firms' decisions. In this sense,

\footnotetext{
9 The confidentiality rules imposed by the Science and Technology Office provide only restricted access to the database and particularly to information on individual organizations and project evaluations.
}

this study could be seen as an example of the utility of administrative information as a first approach to examining the coherence of the decisions made by public agencies, with expected goals.

As already mentioned, a significant novelty of the PROFIT programme was the inclusion of two modes of funding for cooperative projects, which could be implemented simultaneously: subsidies or non-refundable grants, and advance payments (credits without interest). In the period 2000-2003 the total number of cooperative project proposals submitted was 2,790 , of which 1,269 were approved (45.48\%). The average value of the subsidies awarded was $€ 103,034$ per project and the average credit per project was $€ 220,135$. Most of the funded projects $(69.67 \%)$ received a subsidy (and not a credit), while $20.56 \%$ received a credit only. Nearly $10 \%$ of approved projects received both a subsidy and a credit. Tables 2 and 3 present the project information in detail.

Table 3 shows that project budget, planned work hours and expected R\&D outputs are higher in accepted projects, but that this does not apply to number of partners and expected employment. These characteristics hold for the majority of knowledge fields (project budget higher for accepted projects in 12 out of 15 fields, while planned worked hours is higher for accepted projects in 14 out of the 15 fields, and expected R\&D is higher in 11 out of 15 ). 


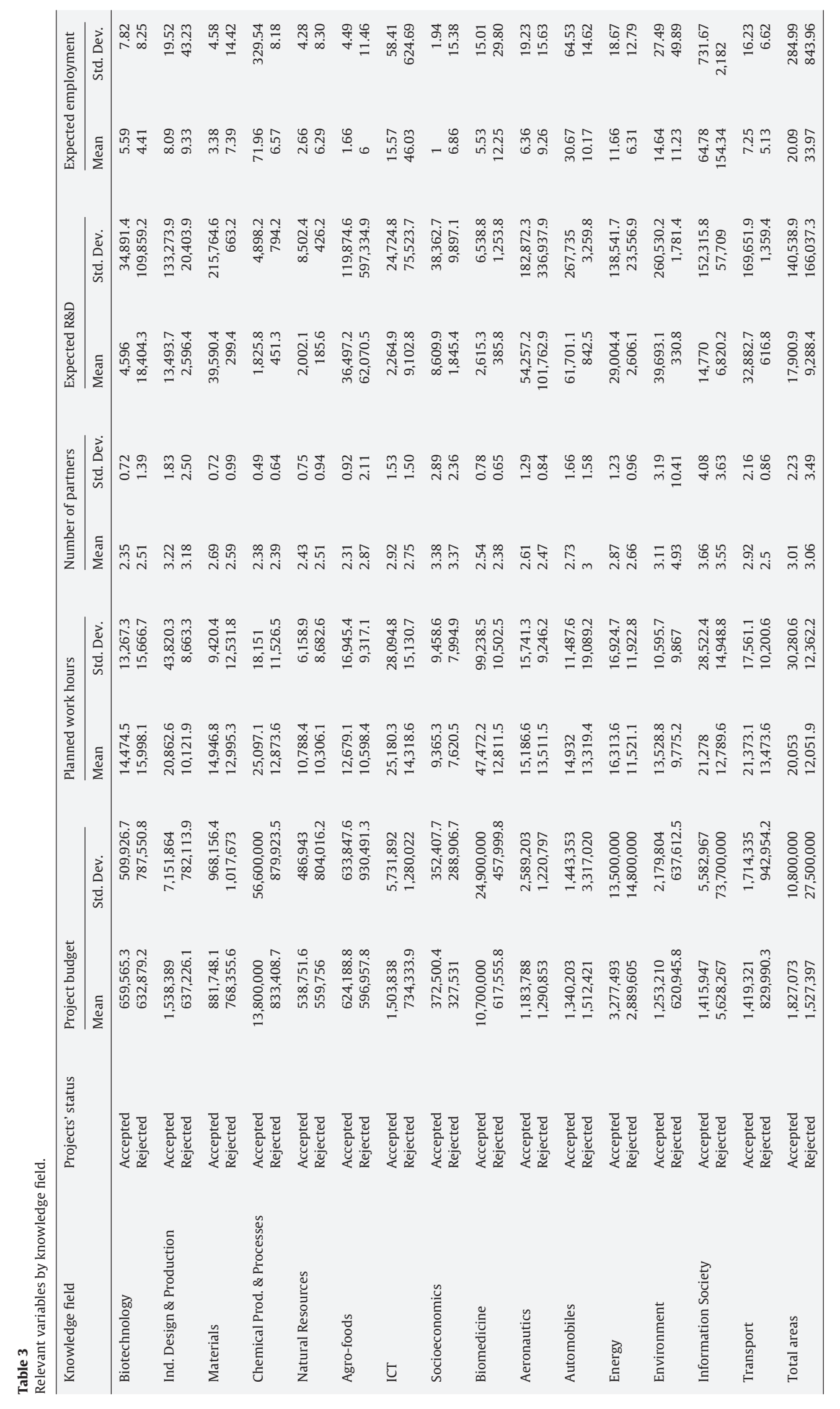


Table 4

Empirical strategy.

\begin{tabular}{|c|c|c|}
\hline Public agency decisions & Empirical question & Method of analysis \\
\hline Step 1: Selecting or rejecting a project & $\begin{array}{l}\text { What are the factors behind the public selection of R\&D } \\
\text { cooperative projects? }\end{array}$ & Probit \\
\hline Step 2: Offering a subsidy and/or a credit & $\begin{array}{l}\text { What are the subtleties in the public selection of R\&D cooperative } \\
\text { projects, where subsidies, credits or both may be assigned? }\end{array}$ & Bivariate probit conditional on selection \\
\hline \multirow[t]{2}{*}{$\begin{array}{l}\text { Step 3: Choosing what percentage of selected } \\
\text { projects' budget to finance }\end{array}$} & $\begin{array}{l}\text { Step 3A: What are the factors behind the percentage of subsidy } \\
\text { awarded? }\end{array}$ & $\begin{array}{l}\text { Upper-limit Tobit conditional on having } \\
\text { received a subsidy }\end{array}$ \\
\hline & $\begin{array}{l}\text { Step 3B: What are the factors behind the percentage of credit } \\
\text { awarded? }\end{array}$ & $\begin{array}{l}\text { Upper-limit Tobit conditional on having } \\
\text { received a credit }\end{array}$ \\
\hline
\end{tabular}

Source: Own elaboration.

It should be noted that projects are larger in some areas, depending on the indicator used: chemical products and process projects are larger for project budget, planned work hours and expected employment, Biomedical projects are bigger in terms of project budget and planned worked hours, Information Society projects are larger for number of partners and expected employment, Socioeconomic projects are larger for number of partners and Aeronautics and Automobile projects rank as large for expected R\&D.

\subsection{Empirical strategy}

The empirical analysis is focused on the three main decisions taken by the public agency in relation to selection of R\&D cooperative projects for funding (Table 4). The funding authority first decides on the projects that will be selected, and then, conditional on acceptance, which type of financial instrument (subsidy and/or credit) will be awarded. Finally, the decision is made about what percentage of the project, conditional on the instrument used, will be financed. In the econometric specification, the first two steps can be modelled as a bivariate probit with selection. First, we model a two-stage process, estimating as a first stage through a probit model and computing the inverse Mills ratio, which is included in the second stage, as a covariate to account for the selection bias. The second stage is estimated as a bivariate probit. ${ }^{10}$ The third stage - percentage of the project to be financed - is modelled using two upper-limit Tobit, that take account of the financial instrument assigned (including the inverse Mills ratio computed to account for the financial instrument selection). The choice of an upper-limit Tobit is based on the fact that there is a cap on the funding offer (100\% in the case of a subsidy and $75 \%$ in the case of a credit).$^{11}$

The first decision that the public evaluator must make is whether to accept or reject the project. The propensity of a project to be selected is assumed to be represented by a latent variable $\left(S^{*}\right)$, which depends on a number of factors derived from the theoretical framework and the objectives of PROFIT. These factors are summarized as project characteristics related to PROFIT goals $\left(X_{j}\right)$ and other factors $\left(Z_{j}\right)$. This reduces the selection mechanism to an equation, on the basis of which the projects are accepted or rejected.

Thus, in order to explore the criteria used by public agency to assess whether or not to select a cooperative project, we estimate a probit model:

$S_{j}^{*}=\beta_{0}+\beta_{1} \cdot X_{j}+\beta_{2} \cdot Z_{j}+\varepsilon_{j}$

The second decision required of the public agency is related to the financial instrument assigned. Conditional on project accep-

\footnotetext{
10 As a sensibility analysis we also estimated two separate probits in this second stage (excluding projects that were awarded both a subsidy and a credit).

11 As another sensibility analysis, we repeated the two Tobit regressions of this third-stage, but excluding the projects that received both subsidy and credit.
}

tance, the agency decides whether to offer a subsidy and/or a credit. Given that a credit (although without interest) is different from a subsidy or a non-refundable grant (in the sense it has to be repaid), it would seem reasonable to expect somewhat different utilization of the credit award compared to a subsidy. However, to our knowledge, no attempts have been made to analyse how the public administration uses these two types of financing within the same call. Some preliminary evidence can be gleaned from data, in that the mean value for credit per project is substantially higher than the mean value for subsidy per project.

As these two types of financial instruments may be related, the error terms in the two probit models (subsidies and credits) are likely to be correlated. Thus, an extension of the probit known as the bivariate probit (Greene, 2000) is usually the most appropriate. Thus, our model has two steps. The first refers to the selection of projects (the first decision) and the second refers to the decision to award a subsidy and/or a credit. This second decision is only observed if the project is selected so that we need to account for sample selection (Greene, 2000).

1) Selection equation:

$S_{j}^{*}=\beta_{0}+\beta_{1} \cdot X_{j}+\beta_{2} \cdot Z_{j}+\varepsilon_{j}$

where $S_{j}=1$ if $S_{j}^{*}>0$, and $S_{j}=0$ in other case

2) Type of funding equation:

$$
\begin{aligned}
& F_{1 j}^{*}=\alpha_{0}^{1}+\alpha_{1}^{1} \cdot X_{j}+\alpha_{2}^{1} \cdot Z_{j}+\mu_{j}^{1} \\
& F_{2 j}^{*}=\alpha_{0}^{2}+\alpha_{1}^{2} \cdot X_{j}+\alpha_{2}^{2} \cdot Z_{j}+\mu_{j}^{2}
\end{aligned}
$$

$$
E\left(\mu_{j}^{1}\right)=E\left(\mu_{j}^{2}\right)=0
$$

where, $\quad \operatorname{Var}\left(\mu_{j}^{1}\right)=\operatorname{Var}\left(\mu_{j}^{2}\right)=1$

$$
\operatorname{Cov}\left(\mu_{j}^{1}, \mu_{j}^{2}\right)=\rho
$$

and $F_{\mathrm{ij}}$ is observed only if $S_{j}=1$, with $F_{1 j}=1$ if $F_{1 j}^{*}>0$ and $F_{2 j}=1$ if $F_{2 j}^{*}>0$ are respectively $F_{1 j}$ subsidies and $F_{2 j}$ credits.

Using this model we try to identify potential subtleties in the factors determining the assignment of a subsidy or a credit, through the estimation of the coefficient vectors $\alpha_{1}^{i}$ and $\alpha_{2}^{i}$, of $\rho$ (the correlation between the error terms $\varepsilon_{i j}$ in the equations), and the standard errors for these parameters. In this estimation procedure, we assume that the perturbations $\varepsilon_{t j}, t=1,2$ are distributed jointly as a bivariate normal. If they are statistically significantly correlated $(\rho \neq 0)$, the bivariate model is more effective than the separate probit models (Greene, 2000, pp. 853-854). ${ }^{12}$ In both equations, we include project characteristics and contextual factors as explanatory variables. We also include as a covariate the inverse Mills ratio computed after the first step to account for the selection bias. In

\footnotetext{
12 And this is the case here, as showed in the sensibility analysis.
} 
order to avoid identification problems (Hamilton and Nickerson, 2003), we exclude two of the variables (Expected investment and Expected employment) in this second-stage estimation.

Finally, the third decision is related to the evaluator's choice about the percentage of the budgets of the selected projects to finance. This decision is conducted in two steps. Step 3A represents the decision related to the percentage of subsidy (conditioned by the award of a subsidy) and step $3 \mathrm{~B}$ represents the decision related to the percentage of credit (conditioned by the award of a credit). Accordingly, we model two upper-limit Tobits, one for subsidies and one for credits. This choice is based on the existence of a cap on the funding that can be offered (100\% for subsidies and $75 \%$ for credits), while there is not constraint regarding the participation decision (lower limit) since we observe only positive outcomes. To account for the selection of the financial instrument we include the corresponding inverse Mills ratio. The model is based on Maddala (1983). Our main concern is in estimating the parameters in the following two-model equations (step $3 \mathrm{~A}$ and step 3B):

Step 3A: $P_{1 j}^{*}=\gamma_{0}^{1}+\gamma_{1}^{1} \cdot X_{j}+\gamma_{2}^{1} \cdot Z_{j}+v_{j}^{1}$

Step 3B : $P_{2 j}^{*}=\gamma_{0}^{2}+\gamma_{1}^{2} \cdot X_{j}+\gamma_{2}^{2} \cdot Z_{j}+v_{j}^{2}$

and

$P_{1 j}=100$ if $P_{1 j}^{*} \geq 100$

$P_{1 j}=P_{1 j}^{*} \quad$ if $P_{1 j}^{*}<100$

$P_{2 j}=75$ if $P_{2 j}^{*} \geq 100$

$P_{2 j}=P_{2 j}^{*} \quad$ if $P_{2 j}^{*}<75$

where $P_{1 j}^{*}$ and $P_{2 j}^{*}$ are the latent variables for the respective percentages of the budget being financed by a subsidy and a credit, and S1 $\mathrm{i}$ and S2i are the endogenous variables so that $P_{1 j}$ is observed only if $F_{1 j}=1$ and $P_{2 j}$ is observed only if $F_{2 j}=1$. Table 4 summarizes our empirical strategy.

\subsection{Variables}

\subsubsection{Dependent variables}

According to our empirical strategy, the first decision is captured by a dichotomous variable (Selected project) that takes the value 1 if the project was selected and 0 if it was rejected. Regarding the second decision, we need to distinguish the financial instrument assigned - credit or subsidy. With this aim, we defined two dichotomous variables: (i) Subsidy, which takes the value 1 if the project was financed by a subsidy; and (ii) Credit, which takes the value 1 if the project was financed by a credit. Neither variable is mutually exclusive because some projects (fewer than $10 \%$ ) are financed by both types of instrument. The third decision is related to the percentage of the project budget to be financed by the PROFIT programme. We capture this decision through two variables: (i) Subsidy financed, which is the percentage of the project budget financed by a subsidy; and (ii) Credit financed, which is the percentage of the project budget financed by a credit.

\subsubsection{Independent variables}

Coherent with our theoretical framework, the factors that explain the public agency's decisions are identified according to their match with PROFIT goals and other control variables.

Regarding the goal of increasing the application of knowledge and incorporation of ideas in the manufacturing process, the database allows us to identify the type of project and the potential effects (expected outputs) of carrying out each project. As mentioned in the PROFIT description, we identified the type of project according to its research orientation. In particular, we identified projects oriented towards basic research (Industrial research), technical viability studies (Viability studies), pre-competitive development projects (Pre-development), technological demonstration projects (Demonstration), diffusion activities (Diffusion), and actions to promote participation in international cooperative R\&D programmes (International). We captured these effects by means of six dichotomous variables, using Industrial research as the reference category. Regarding expected outputs, we can analyse this effect on the selection process and financing decisions through the variables for expected growth in R\&D expenses (expected $R \mathcal{E} D$ ), expected industrial investments (expected investments), and expected employment (expected employment) as project outcomes. In order to avoid identification problems, we employ the variables Expected investments and Expected employment only in the first stage estimation. We do not exclude Expected $R \mathcal{E} D$ given that it fits with one explicit selection criterion in the PROFIT initiative.

Another factor that we need to account for in our empirical analysis is the industry effect; however, lack of individual firm data means that we need to use information on technological and sectoral areas of projects to proxy for some industry characteristics. We consider the variables associated with several knowledge fields which represent priorities in Spanish technology policy and are included in the PROFIT programme. We look particularly at Biotechnology, Industrial Design and Production, Materials, Chemical Products and Processes, Natural Resources, Agro-foods, Information and Communication Technologies, Biomedicine and Socioeconomics. It also includes sectoral areas such as Aeronautics, Automobiles, Energy, Environment, Information Society and, Transport and Territorial Arrangements. We captured the effects of these technological and sectoral areas by means of 15 dichotomous variables. Industrial Design and Production is the reference category.

The database provides information related to the goal of promoting cooperation among the different agents involved in the science-technology-firm system. In particular, to check the influence of research organizations (universities and TIs) in the project selection process, we constructed two dichotomous variables reflecting whether Universities and/or Technology Institutes were among the project partners. In addition, we can measure the number of organizations involved in the project (Partners) in order to analyse the influence of consortium size.

In order to capture other factors beyond PROFIT goals the database allows us to identify the year of the call, the applicant's region, and the project size. We want to control for the year of the project proposal in order to capture fluctuations in the annual demand for funds or the effect of annual budget cycles. We constructed four dichotomous variables related to the year of the call (Year 2000; Year 2001; Year 2002 and Year 2003); Year 2000 is the reference category. To capture regional differences, we employed a dummy for each Spanish region with at least one organization involved in a project. Here, it is important to take account of the fact that several organizations are involved in each project, and these organizations may be located in different regions. $48.48 \%$ of projects involve organizations from at least two different regions and $11.47 \%$ of projects involve organizations from at least three regions. Thus, we avoid multicollinearity problems if we include all regions in the estimation process. Finally, we measured the total planned number of working hours by qualified personnel (Hours), which could be interpreted as a proxy for project size. Also, related to project size we included the total amount of the project budget (Budget).

Table 5 provides descriptive statistics and correlations of the independent variables used in the study. The Appendix B provides a description of how the variables were constructed. 


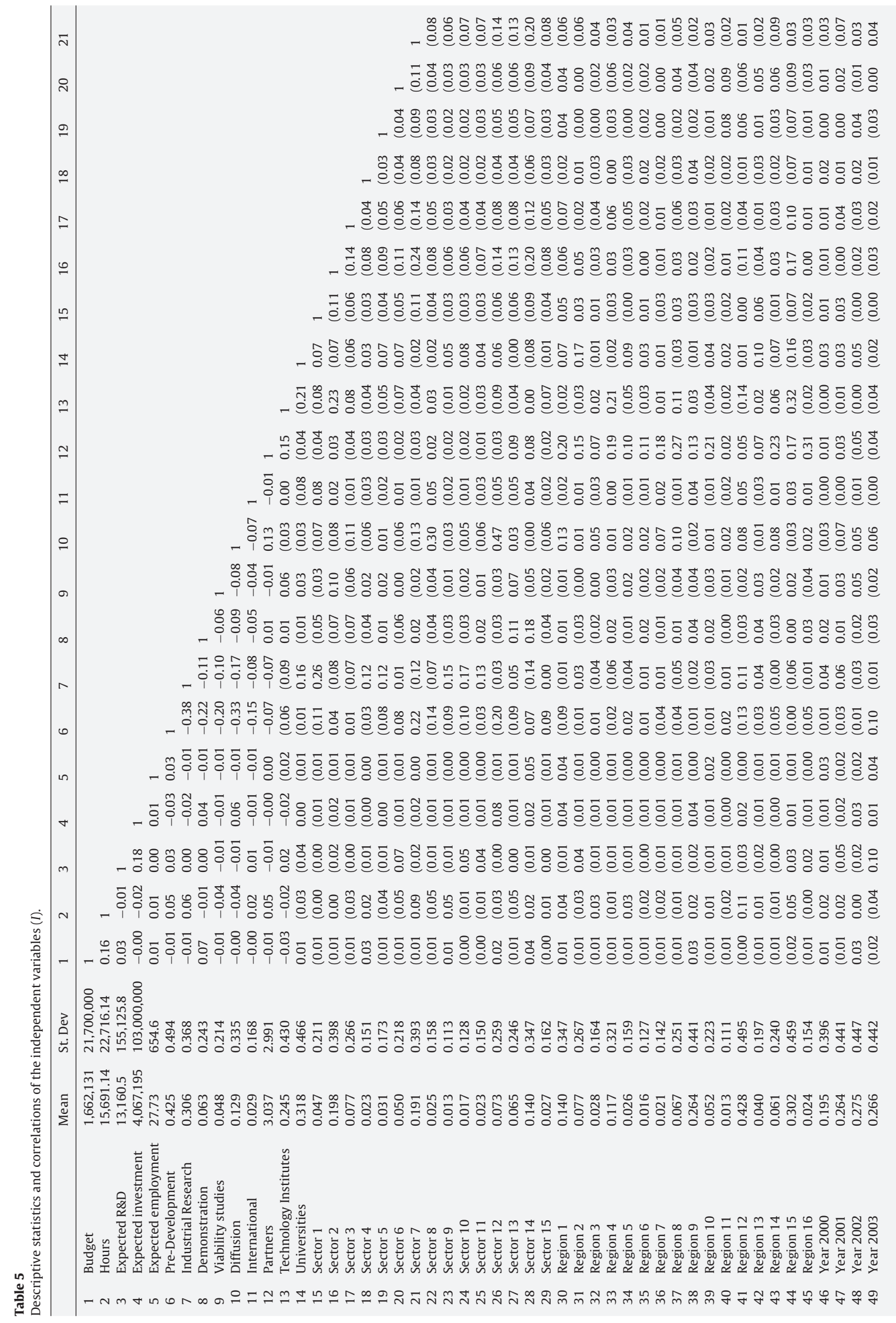




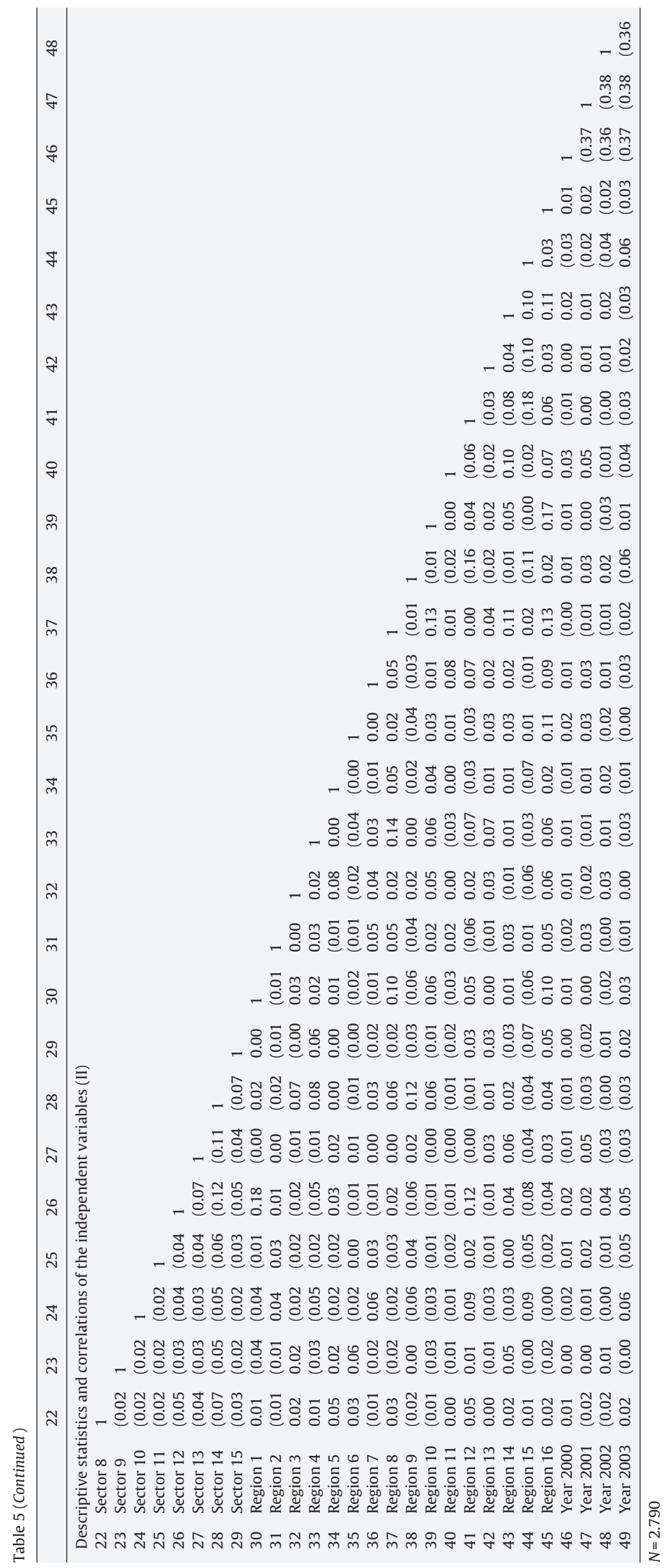


Table 6

Selection of R\&D cooperative projects (Step 1).

\begin{tabular}{|c|c|}
\hline & $\begin{array}{l}\text { Model } 1 \text { (Probit) } \\
\text { Selected project }\end{array}$ \\
\hline Pre-development & $0.229^{* * * *}(3.47)$ \\
\hline Demonstration & $0.197^{\circ}(1.74)$ \\
\hline Viability Studies & $0.300^{* * *}(2.43)$ \\
\hline Diffusion & $0.208^{* * *}(2.03)$ \\
\hline International & $1.009^{\circ+4+}(6.14)$ \\
\hline Expected R\&D & $0.014(0.52)$ \\
\hline Expected investment & $0.302^{* *}(2.55)$ \\
\hline Expected employment & $(0.034((1.36)$ \\
\hline Sector 1 & $(0.061((0.45)$ \\
\hline Sector 3 & $\left(0.645^{\circ * 4}((5.87)\right.$ \\
\hline Sector 4 & $(0.174((1.05)$ \\
\hline Sector 5 & $\left(0.688^{* *+*}((4.04)\right.$ \\
\hline Sector 6 & $\left(0.674^{-* *+1}((4.94)\right.$ \\
\hline Sector 7 & $(0.076((0.94)$ \\
\hline Sector 8 & $\left(0.617^{* *+*}((3.40)\right.$ \\
\hline Sector 9 & $(0.356((1.52)$ \\
\hline Sector 10 & $0.408^{-* *}(2.01)$ \\
\hline Sector 11 & $0.724^{*+*+}(3.73)$ \\
\hline Sector 12 & $\left(0.277^{* *}((2.19)\right.$ \\
\hline Sector 13 & $\left(0.222^{* * *}((2.01)\right.$ \\
\hline Sector 14 & $\left(0.179^{* *}((1.99)\right.$ \\
\hline Sector 15 & $(0.118((0.72)$ \\
\hline Universities & $0.081(1.39)$ \\
\hline Technology Institutes & $(0.058((0.88)$ \\
\hline Partners & $(0.025((1.46)$ \\
\hline Year 2001 & $\left(0.188^{* *+}((2.42)\right.$ \\
\hline Year 2002 & $\left(0.299^{* * * *}((3.83)\right.$ \\
\hline Year 2003 & $0.009(0.11)$ \\
\hline Region 1 & $(0.095((1.20)$ \\
\hline Region 2 & $(0.001)((0.01)$ \\
\hline Region 3 & $\left(0.303^{\circ}((1.86)\right.$ \\
\hline Region 4 & $0.306^{*+*+}(3.62)$ \\
\hline Region 5 & $(0.075((0.45)$ \\
\hline Region 6 & $(0.024((0.12)$ \\
\hline Region 7 & $(0.139((0.80)$ \\
\hline Region 8 & $(0.090((0.87)$ \\
\hline Region 9 & $(0.048((0.77)$ \\
\hline Region 10 & $\left(0.206^{\circ}((1.72)\right.$ \\
\hline Region 11 & $0.279(1.15)$ \\
\hline Region 12 & $0.235^{* * *}(4.15)$ \\
\hline Region 13 & $0.054(0.41)$ \\
\hline Region 14 & $0.133(1.20)$ \\
\hline Region 15 & $0.226^{* *+4}(3.43)$ \\
\hline Region 16 & $0.087(0.46)$ \\
\hline Budget & $\left(0.033^{\circ}\right)((1.72)$ \\
\hline Hours & $0.377^{* *+}(8.13)$ \\
\hline Constant & $(0.067((0.64)$ \\
\hline Number of observations & 2790 \\
\hline Wald test of full model: $\chi^{2}$ & $306.47^{* * *}$ \\
\hline Log pseudo-likelihood & $(1732.62$ \\
\hline
\end{tabular}

Robust $z$-statistic shown in parenthesis.

$p<0.10$.

** $p<0.05$.

$p<0.01$.

\section{Empirical analysis}

The empirical analysis follows the three stages proposed in the empirical strategy. First, we analyse the factors underlying the public selection of R\&D cooperative projects. Second, for selected projects, we explore the subtleties involved in the assignment of subsidies and/or credits. Third, we examine the factors influencing what percentage of the budget to finance.

\subsection{Results for the first step: project selection}

Table 6 provides empirical evidence on the factors that underlie public selection of cooperative R\&D projects (Model 1). Analysis of this first decision is critical given that it identifies what determines selection of exclusion of a project from the PROFIT initiative.

Results show that project characteristics related to PROFIT goals are very influential in the agency's selection decision. First, there is a preference for projects that are closer to the market than those related to basic research. In particular, Pre-Development, Demonstration, Viability Studies, and Diffusion projects are more frequently funded than Industrial Research projects (control category). Second, in relation to expected outputs, projects with higher expected investment are also preferred, but neither expected employment opportunities nor R\&D is significant. Third, there are many selection differences across knowledge areas. The probability of funding is higher for Automobiles and Aeronautics projects than for Design and Industrial Production (reference category) projects, while funding of Materials, Natural Resources, Agro-foods, Socioeconomics, Energy, Environment and Information Society projects is less likely compared to the reference category. Fourth, the variables related to cooperation generally do not show any significant influence on the probability of a project's being selected, the exception being projects related to International Cooperation, which shows a high probability of being selected.

There are other factors in addition to PROFIT goals that exert a significant influence on the initial decision to select a project. First, we find that the year of the proposal is relevant. More precisely, projects in 2001 and 2002 (the mid point years in the PROFIT initiative) were more frequently rejected than proposals submitted in 2000 (reference year). Second, there are regional disparities: projects with the participation of organizations from C. Valenciana, Madrid and País Vasco have a significantly higher chance of being selected, while applications from Baleares and Galicia are less likely to be awarded funding. Finally, the two variables measuring project inputs are both statistically significant. More precisely, the public agency gives preference to projects with high numbers of working hours and low budgets.

\subsection{Results of the second step: assigning the financial instrument}

The use of two different financial instruments in the PROFIT initiative involves a much more detailed analysis of the behaviour of the public agency allocating resources to cooperative projects. Taking account of the first decision to select or reject a project, the next step is whether to assign a subsidy and/or a credit. Table 7 presents the bivariate probit model estimation for the subtleties in the public assignment of credits and subsidies (Model 2). The test reveals that correlation of the error terms of the two models (subsidies and credits) is statistically significant, which is an indication that the bivariate model is more effective than the separate probit models (Greene, 2000, pp. 853-854). In order to account for selection bias we included as a covariate the inverse Mills ratio computed from the first stage. The fact that it is significant shows that selection exists and that the use of this variable enables unbiased estimates.

As in the first stage, several factors related to PROFIT goals are important in the assignment of the financial instrument. Concerning type of project, Pre-Development and Demonstration projects have a higher probability than Industrial Research projects of being awarded a credit and a lower probability of being awarded a subsidy, while Diffusion projects have a lower probability of receiving a credit. Expected R\&D does not have an impact on the award of either a subsidy or a credit. In terms of knowledge areas, some are less likely to receive a subsidy compared to Design and Industrial Production projects (Chemical Products and Processes, Biomedicine, Energy and Environment) and some are less likely to receive a credit (Materials, ICTs and Information Society). Chemical Products and Processes and Automobiles projects are more likely to be awarded credit. In relation to cooperation, participation of a university or a $\mathrm{TI}$ increases the probability of a subsidy and decreases the proba- 
Table 7

Assignment of subsidies and credits conditional on selection (Step 2).

\begin{tabular}{|c|c|c|}
\hline & \multicolumn{2}{|c|}{ Model 2 (Bivariate probit with selection) } \\
\hline & Subsidy & Credit \\
\hline Pre-development & $\left(0.739^{* * *}((5.03)\right.$ & $0.663^{* * *}(4.96)$ \\
\hline Demonstration & $\left(0.742^{* * *}((3.44)\right.$ & $0.567^{* * *}(2.82)$ \\
\hline Viability Studies & $0.012(0.04)$ & $0.283(1.30)$ \\
\hline Diffusion & $0.284(1.24)$ & $\left(0.392^{*}((1.84)\right.$ \\
\hline International & $1.126^{* *+*}(2.80)$ & $\left(0.885^{* *+*}\right)((2.73)$ \\
\hline Expected R\&D & $0.079(1.54)$ & $(0.049((0.85)$ \\
\hline Sector 1 & $0.112(0.68)$ & $(0.139)((0.82)$ \\
\hline Sector 3 & $0.296(0.95)$ & $\left(0.957^{* * *}((3.12)\right.$ \\
\hline Sector4 & $\left(1.341^{* * *}((4.51)\right.$ & $0.784^{* * *}(2.73)$ \\
\hline Sector 5 & $(0.575((1.20)$ & $0.421(1.03)$ \\
\hline Sector 6 & $(0.561((1.27)$ & $(0.078((0.20)$ \\
\hline Sector 7 & $0.169(1.21)$ & $\left(0.525^{* *+}((4.18)\right.$ \\
\hline Sector 8 & $(0.012((0.21)$ & $0.039(0.51)$ \\
\hline Sector 9 & $\left(1.001^{* * *}((2.31)\right.$ & $0.177(0.41)$ \\
\hline Sector 10 & $(0.401((1.32)$ & $0.079(0.27)$ \\
\hline Sector 11 & $0.339(1.11)$ & $0.606^{* *}(2.10)$ \\
\hline Sector 12 & $\left(0.520^{* *}((1.98)\right.$ & $0.373^{*}(1.70)$ \\
\hline Sector 13 & $\left(0.603^{* * *}((3.03)\right.$ & $0.294(1.55)$ \\
\hline Sector 14 & $0.219(1.28)$ & $\left(0.686^{* * * *}((4.28)\right.$ \\
\hline Sector 15 & $(0.313((1.25)$ & $(0.020((0.08)$ \\
\hline Universities & $1.173^{* * *}(9.27)$ & $\left(0.843^{* * * *}\right)((8.08)$ \\
\hline Technology Institutes & $0.831^{* * *}(5.91)$ & $\left(0.855^{* * *}\right)((6.64)$ \\
\hline Partners & $(0.030((0.88)$ & $(0.021((0.58)$ \\
\hline Year 2001 & $\left(0.280^{\circ}((1.90)\right.$ & $0.227^{\circ}(1.72)$ \\
\hline Year 2002 & $\left(0.365^{* *}((2.35)\right.$ & $0.296^{* *}(2.02)$ \\
\hline Year 2003 & $0.027(0.19)$ & $(0.001((0.01)$ \\
\hline Region 1 & $0.301^{*}(1.69)$ & $\left(0.369^{* *}((2.26)\right.$ \\
\hline Region 2 & $0.168(0.76)$ & $(0.081((0.46)$ \\
\hline Region 3 & $(0.185((0.51)$ & $0.052(0.15)$ \\
\hline Region 4 & $0.533^{* \ldots *}(2.83)$ & $\left(0.385^{\circ *}((2.27)\right.$ \\
\hline Region 5 & $0.469(1.22)$ & $(0.537((1.52)$ \\
\hline Region 6 & $0.129(0.32)$ & $0.131(0.38)$ \\
\hline Region 7 & $(0.092((0.28)$ & $(0.018((0.05)$ \\
\hline Region 8 & $0.086(0.35)$ & $(0.231((0.99)$ \\
\hline Region 9 & $(0.062((0.49)$ & $0.152(1.35)$ \\
\hline Region 10 & $(0.294((1.19)$ & $0.221(0.98)$ \\
\hline Region 11 & $0.022(0.05)$ & $0.171(0.42)$ \\
\hline Region 12 & $0.371^{* \ldots+}(2.88)$ & $(0.175((1.55)$ \\
\hline Region 13 & $0.013(0.04)$ & $(0.034((0.13)$ \\
\hline Region 14 & $(0.166((0.88)$ & $0.137(0.74)$ \\
\hline Region 15 & $0.179(1.27)$ & $(0.123((0.97)$ \\
\hline Region 16 & $(0.064((0.23)$ & $0.129(0.45)$ \\
\hline Budget & $\left(0.418^{\circ}\right)((1.87)$ & $0.279(1.19)$ \\
\hline Hours & $0.191^{\circ *}(2.40)$ & $0.068(0.93)$ \\
\hline Constant & $(0.358((0.83)$ & $0.521(1.30)$ \\
\hline Inverse Mills Ratio & $1.431^{* * *}(3.43)$ & $\left(0.912^{* *}\right)((2.33)$ \\
\hline Number of observations & 1269 & \\
\hline $\mathrm{LR} \sim \chi^{2}: \rho=0$ & $\chi^{2}=623.91^{* * *}$ & \\
\hline Wald test of full model: $\chi^{2}$ & $383.38^{* * *}$ & \\
\hline Log pseudo-likelihood & $(757.57$ & \\
\hline
\end{tabular}

Robust $z$-statistic shown in parenthesis.

$p<0.10$.

"* $p<0.05$.

*** $p<0.01$.

bility of a credit. Number of partners has no influence on the award of either type of financial instrument. Finally, projects related to International Cooperation are associated with a higher probability of receiving a subsidy and a lower probability of receiving a credit.

Other factors include year differences. The model shows that fewer subsidies but more credits were awarded in 2001 and 2002 compared to 2000 . There are also some regional differences. Projects from Madrid, Andalucía and Comunidad Valenciana are positively related to the award of a subsidy, while project applications from Andalucía and Comunidad Valenciana are negatively related to the assignment of credits. In terms of project inputs, number of hours worked positively affects the award of a subsidy, while the influence of project budget is negative. However, neither input has a significant influence on the assignment of a credit. Finally, we conducted a sensibility analysis in order to explore the effect when projects awarded both subsidies and credits (122 in total) were excluded and, thus, independent probits, were applied. The results in Annex 1 show that there are hardly any differences.

\subsection{Results of the third step: budget financed}

The third step in our empirical strategy is to analyse the factors influencing the percentage of the budget financed, conditional on second step decision (assignment of a subsidy and/or a credit). We estimated two upper-limit Tobits to account for the cap on the amount of funding provided (100\% for subsidies and $75 \%$ for credits). To account for which financial instrument is selected we included the inverse Mills ratio computed from the second stage. Table 8 shows the results of the two upper limit Tobits for estimating factors that influence the percentage of subsidy financed (Model 3A) and the percentage of credit financed (Model 3B).

Concerning type of project, Pre-Development and Demonstration projects receive lower percentages of subsidies than do Industrial Research projects, while Demonstration and Diffusion projects receive higher proportions of credits. Viability studies are awarded a lower percentage of credits, while expected R\&D shows no differences in relation to percentage of credits or subsidies. In terms of knowledge areas, some (Aeronautics and Information Society) receive higher percentages of both subsidies and credits, while Automobiles receives a lower percentage of both types of financing. Biomedicine and ICT projects receive higher percentages of credit. Materials, Chemicals, Biomedicine, Agro-foods and Energy projects receive lower percentages of subsidy. If universities or TI are involved, the percentage of the budget subsidized is higher, while the proportion of credit is lower if one of the project partners is a university. Number of partners has a negative effect on the percentage of subsidy funding.

Regarding year differences, in 2001 the percentages of subsidy and credit were both low; in 2002 the percentage of subsidies was lower than in 2000, and in 2003 only the percentage of credit was higher. In terms of regional effects, projects with participation from organizations in certain regions, such as Andalucía, C. Valenciana, Canarias, Madrid, Murcia and País Vasco, received higher percentages of subsidy (but not credit) while projects with participation of organizations from Navarra received lower percentages of subsidy (but not credit). Projects with partners from Cantabria receive a lower percentage of credit (but not subsidy), while the reverse is true for projects with partners from Baleares and Asturias (higher percentage of credit, though no effect on subsidies). For inputs, project budget has a negative effect only on the percentage of credit financing (with no influence on subsidies). In contrast to previous analyses, number of hours worked is no longer important, that is, it does not affect the percentage of either credit or subsidy received.

Finally, as in the second stage, a sensibility analysis was conducted in order to explore the robustness of our results when excluding projects awarded both a subsidy and a credit: the results hardly differ (Annex 2).

\section{Summary of findings and concluding remarks}

The objective of this paper was to analyse the process of selection for cooperative R\&D projects within the Spanish PROFIT initiative. The study explored three important aspects: (a) the factors underlying project selection and resource allocation; (b) the coherence between the public agency's decisions and the main goals of the funding programme; and (c) the particularities behind the simultaneous use of subsidies and credits. We based our empirical analysis on project level data from the Spanish PROFIT initiative 
Table 8

Funding of R\&D cooperative projects by financial instrument (Step 3).

\begin{tabular}{|c|c|c|}
\hline & $\begin{array}{l}\text { Model 3A (upper } \\
\text { limit Tobit) } \\
\text { Subsidy financed }\end{array}$ & $\begin{array}{l}\text { Model 3B (upper } \\
\text { limit Tobit) } \\
\text { Credit financed }\end{array}$ \\
\hline Pre-development & $-0.111^{* * *}(-6.85)$ & $0.037(1.46)$ \\
\hline Demonstration & $-0.073^{* * *}(-3.00)$ & $0.095^{* * * *}(2.92)$ \\
\hline Viability Studies & $-0.011(-0.39)$ & $-0.117^{*+*}(-2.63)$ \\
\hline Diffusion & $0.022(0.76)$ & $0.120^{* *}(2.25)$ \\
\hline International & $0.089(1.54)$ & $-0.007(-0.07)$ \\
\hline Expected R\&D & $-0.002(-0.37)$ & $0.005(0.53)$ \\
\hline Sector 1 & $-0.046^{\circ}(-1.68)$ & $-0.067(-0.95)$ \\
\hline Sector 3 & $-0.143^{\circ * *}(-3.71)$ & $-0.007(-0.14)$ \\
\hline Sector 4 & $-0.295^{\circ * *}(-4.76)$ & $-0.038(-0.99)$ \\
\hline Sector 5 & $-0.022(-0.30)$ & $0.009(0.22)$ \\
\hline Sector 6 & $-0.103^{\circ}(-1.95)$ & $-0.054(-1.32)$ \\
\hline Sector 7 & $0.027(1.44)$ & $0.130^{*+* * *}(4.55)$ \\
\hline Sector 8 & $0.017(0.31)$ & $0.004(0.08)$ \\
\hline Sector 9 & $-0.098^{\circ}(-1.83)$ & $0.161^{* * * *}(2.89)$ \\
\hline Sector 10 & $0.110^{* * *}(2.51)$ & $0.137^{* * * *}(3.02)$ \\
\hline Sector 11 & $-0.098^{\circ *}(-2.34)$ & $-0.089^{* *}(-2.17)$ \\
\hline Sector 12 & $-0.144^{* * *}(-3.83)$ & $0.021(0.39)$ \\
\hline Sector 13 & $-0.033(-0.90)$ & $0.047^{*}(1.71)$ \\
\hline Sector 14 & $0.041^{* *}(2.04)$ & $0.143^{*+*+*}(4.49)$ \\
\hline Sector 15 & $0.025(0.60)$ & $0.056(0.96)$ \\
\hline Universities & $0.199^{* * *}(6.33)$ & $-0.115^{*+* *}(-4.22)$ \\
\hline Technology Institutes & $0.084^{* * *}(4.54)$ & $-0.022(-0.72)$ \\
\hline Partners & $-0.008^{* * *}(-2.37)$ & $0.008(1.33)$ \\
\hline Year 2001 & $-0.039^{* *}(-1.99)$ & $-0.061^{* *}(-2.51)$ \\
\hline Year 2002 & $-0.079^{* * *}(-3.56)$ & $-0.026(-0.97)$ \\
\hline Year 2003 & $0.006(0.43)$ & $0.073^{*+* *}(2.68)$ \\
\hline Region 1 & $0.033^{\circ}(1.90)$ & $-0.036(-1.19)$ \\
\hline Region 2 & $0.007(0.35)$ & $-0.018(-0.54)$ \\
\hline Region 3 & $-0.052(-1.30)$ & $0.083^{*}(1.69)$ \\
\hline Region 4 & $0.104^{*+*}(4.43)$ & $0.007(0.21)$ \\
\hline Region 5 & $0.163^{* * *}(3.09)$ & $-0.089(-1.57)$ \\
\hline Region 6 & $0.088^{\circ}(1.83)$ & $-0.163^{*}(-1.78)$ \\
\hline Region 7 & $-0.049(-1.26)$ & $0.045(0.80)$ \\
\hline Region 8 & $0.025(1.05)$ & $-0.024(-0.48)$ \\
\hline Region 9 & $-0.001(-0.01)$ & $-0.009(-0.45)$ \\
\hline Region 10 & $-0.027(-0.78)$ & $0.035(0.79)$ \\
\hline Region 11 & $-0.016(-0.26)$ & $0.025(0.51)$ \\
\hline Region 12 & $0.092^{* * *}(4.01)$ & $-0.021(-1.06)$ \\
\hline Region 13 & $0.057^{* *}(2.11)$ & $-0.006(-0.12)$ \\
\hline Region 14 & $-0.051^{* *}(-2.44)$ & $-0.024(-0.61)$ \\
\hline Region 15 & $0.036^{\circ}(1.84)$ & $-0.009(-0.46)$ \\
\hline Region 16 & $-0.006(-0.14)$ & $0.092^{*}(1.84)$ \\
\hline Budget & $-0.042(-1.47)$ & $-0.020^{4+*}(-4.57)$ \\
\hline Hours & $-0.003(-0.30)$ & $0.001(0.10)$ \\
\hline Constant & $0.121^{\circ}(1.78)$ & $0.574^{* * *}(9.17)$ \\
\hline Inverse Mills Ratio & $0.245^{* * * *}(2.65)$ & $0.001(0.03)$ \\
\hline Number of observations & 1007 & 384 \\
\hline Log likelihood & -322.15 & -133.98 \\
\hline
\end{tabular}

Robust $z$-statistic shown in parenthesis.

$p<0.10$

** $p<0.05$

$p<0.01$.

in the period 2000-2003 in order to investigate these aspects. The econometric specification followed the three steps of the public agency's decision-making process in the PROFIT programme. That is, to select or reject a project; to assign a credit and/or a subsidy; and to decide what percentage of the budget would be financed using these tools.

In order to understand this decision-making process, we analysed the roles played by several project characteristics related to PROFIT goals, as well as some other factors. This allowed us to identify drivers whose impact on project selection and funding differs. Moreover, as expected, there are differences in the use of credits and subsidies. The reason why the Spanish Government implemented the two instruments in the same call probably was to make a distinction among project proposals through the award of a credit or a subsidy. Table 9 summarizes these public choice drivers by classifying them into a typology of four groups: (i) those that contribute positively to both selection and funding (Type 1: 'High support'); (ii) those that contribute positively to selection, but not funding (Type 2: 'Something for everybody'); (iii) those that do not influence selection but do influence funding (Type 3: 'Selective support'); and (iv) those that do not affect public choice of a project nor its funding (Type 4: 'Low support'). Table 9 also shows selection among these factors based on the financial instrument applied (subsidy or credit or both)

Type of project is highly relevant in the selection process. In the first stage there is a clear preference for projects that are closer to the market than basic research programmes (i.e. Industrial Research projects). This result is in line with the PROFIT goal of increasing the application of knowledge, and with the selection criterion of applicability of results. If we differentiate between credits and subsidies we observe that some projects closer to market (Demonstration, Diffusion) are more likely to be awarded credit while for Pre-Development and Viability studies there is something for everyone, again based on credit. Finally, projects that are far from the market (Industrial Research) receive selective support through subsidies. In other words, the agency uses the two financial tools to address different objectives.

In terms of outputs, expected investment seems to increase the probability of a project being selected. However, expected R\&D does not exert a significant influence along the selection process. Accordingly, the selection criteria of increasing R\&D activity is not addressed by higher support for projects whose results could serve as inputs for future R\&D projects.

In terms of knowledge areas, we observe that, irrespective of the financial tool, some areas (Aeronautics) receive high levels of support, some receive selective support (Information Society), while in other areas (Automobiles) there is something for everybody and others receive low support (Natural Resources, Socioeconomic, Environment). However, we also find differences between the financial tools. More traditional sectors, such as Industrial Design and Production, receive high support through subsidies, and new technologies (Biomedicine and ICTs) are selectively supported using credits. Similarly, other technology intensive areas (Materials, Chemicals, Agro-foods, Energy) receive low support through subsidies. That is, the agency uses the financial tools to make compatible the existence of different objectives.

Concerning cooperative factors, there is a 'selective support', basically through subsidies, of projects with the involvement of a university and/or a TI. This result show a partial coherence with the PROFIT goal of promoting cooperation among the different agents in the science-technology-firm system. This 'selective support' for projects with TI involvement is also coherent with the explicit addition of these organizations in the public call. Contrary to our expectations, number of partners does not have a positive effect on project selection and funding ('low support'). In this case, the PROFIT initiative does not seem to foster large consortia. On the other hand, the specific and strong support for projects oriented towards international R\&D cooperation is aligned to the PROFIT goal of encouraging cooperation. In international projects there is something for everybody, but in the form of subsidies.

In relation to other factors underlying the selection process there are differences in terms of year of the call. In 2001 there was 'low support', especially through subsidies (and in 2001 also credits), while in 2000 there was 'high support' from both types of funding. There are several possible explanations for this. First, the higher rate of acceptance in the first year works to increase the number of applications in subsequent years. Second, the allocation of funds in 2000 was out of proportion, and reduced the amount of resources available for subsequent years. We can see that in 2003 (the final year of the PROFIT initiative) projects received 'selective 
Table 9

Summary of public choice drivers.

\begin{tabular}{|c|c|c|c|c|}
\hline $\begin{array}{l}\text { Financial instrument used } \\
\text { to discriminate projects }\end{array}$ & Type 1: High support & $\begin{array}{l}\text { Type 2: Something for } \\
\text { everybody }\end{array}$ & Type 3: Selective support & Type 4: Low support \\
\hline \multirow[t]{6}{*}{ Basically subsidies } & & Input: Hours & & \\
\hline & & Type of project: International & $\begin{array}{l}\text { Type of project: Industrial Research } \\
\text { Cooperation: Universities, } \\
\text { Technology Institutes }\end{array}$ & Cooperation: Partners \\
\hline & Knowledge area: Industrial & & & Knowledge area: \\
\hline & Design and Production & & & $\begin{array}{l}\text { Materials; Chemicals; } \\
\text { Agro-foods; Energy }\end{array}$ \\
\hline & $\begin{array}{l}\text { Region: C. Valenciana; Madrid; } \\
\text { País Vasco }\end{array}$ & & Region: Andalucía; Canarias; Murcia & Region: Navarra \\
\hline & & & & Year of the call: 2002 \\
\hline \multirow[t]{4}{*}{ Basically credits } & Type of project: Demonstration; & Type of project: & & \\
\hline & Diffusion & $\begin{array}{l}\text { Pre-Development; Viability } \\
\text { Studies }\end{array}$ & & \\
\hline & & & Knowledge area: Biomedicine; ICTs & \\
\hline & & & $\begin{array}{l}\text { Region: Baleares; Asturias } \\
\text { Year of the call: } 2003\end{array}$ & Region: Cantabria \\
\hline \multirow{7}{*}{$\begin{array}{l}\text { Both instruments without } \\
\text { distinction }\end{array}$} & & Expected output: Investment & & Input: Budget \\
\hline & Knowledge area: Aeronautics & Knowledge area: Automobiles & Knowledge area: Information & Knowledge area: \\
\hline & & & Society & Natural Resources; \\
\hline & & & & Socioeconomics; \\
\hline & & & & Environment \\
\hline & & & & Region: Galicia \\
\hline & Year of the call: 2000 & & & Year of the call: 2001 \\
\hline
\end{tabular}

support' through credits. This shows that PROFIT did not fulfil the requirement that public initiatives need to be stable to induce confidence in target organizations (Shapira et al., 1995; Acosta and Modrego, 2001).

In terms of regional differences, projects that included organizations from Madrid, País Vasco and C. Valenciana received 'high support' through subsidies. There was 'selective support' through subsidies for projects with organizations from Andalucía, Canarias and Murcia, and through credits for projects with organizations from Baleares and Asturias, while projects with participation from Navarra, Cantabria and Galicia received 'low support'. We cannot say whether these regional differences are due to political reasons or the industry particularities of the region. However, there would seem to be a relationship between the degree of development of the region and the support received, with the exception perhaps of Cataluña, one of the more developed regions in Spain which does not seem to be particularly favoured in terms of either selection or funding. Overall, these results support the arguments in Vence (1998), that public R\&D initiatives are usually focused on encouraging technological capacity to the detriment of regional cohesion.

Finally, regarding project inputs, there is a different impact of number of working hours planned and project budget. The public agency shows a high propensity to select projects with high numbers of working hours and small budgets. If we differentiate by financial instrument, we discovered that projects with large budgets are given proportionately less support via either type of instrument and that projects with large numbers of work hours usually receive some funding through subsidies (Type 2: Something for everybody).

To summarize, our analysis reveals that the model proposed in this paper is useful to understand the criteria used for public selection among cooperative R\&D projects. In deciding how to select a project and how much it will be awarded, the public agency considers a set of factors, and the financial tools at its disposal. Our understanding of public agency behaviour would be enhanced were we given access to data on organizational characteristics, which would complete the picture of the factors underlying the public selection and financing of cooperative R\&D projects. However, the present study complements the research carried out by Acosta and
Modrego (2001) and Blanes and Busom (2004), which focuses on organizations' decisions to apply for public support for R\&D.

This research has some implications-including that public behaviour does not always fit perfectly with declared objectives, and there is a need for public decisions to be evaluated and for the process to be more transparent. Learning about policy is not straightforward (Nauwelaers and Wintjes, 2002), mainly because evaluation studies encounter huge difficulties in relation to scarcity of data (Cozzarin, 2008) and such evaluations that are performed are seldom published (Feller et al., 1996). Future research should try to develop a comprehensive database that allows: (i) taking account of the characteristics of organizations; (ii) technical evaluation of referees; and (iii) takes account of the characteristics of non-applicant organizations. It would also be interesting to analyse several public initiatives in combination, to investigate whether and to what extent they are complementary. We are aware of the difficulty of such a task because of lack of data on the project evaluation process. However, such an exercise would improve the coherence of the public agency's goals with funding decisions and project characteristics.

\section{Acknowledgment}

This project was financed by the Spanish Science and Technology Office. We want to thank Íñigo Segura and Juan Carlos Castro for their insights on and contributions to this work and specially to the two referees who devoted much effort to our paper and gave very useful comments. Usual disclaimers apply.

\section{Appendix A. Supplementary data}

Supplementary data associated with this article can be found, in the online version, at doi:10.1016/j.respol.2010.01.011.

\section{References}

Acosta, J., Modrego, A., 2001. Public financing of cooperative R\&D projects in Spain: the Concerted Projects under the National R\&D Plan. Research Policy 30, $625-641$. 
Arrow, K.J., 1962. Economic welfare and the allocation of resources for invention. In: Nelson, R.R. (Ed.), The Rate and Direction of Inventive Activity. Princeton University Press, Princeton, NJ.

Becker, W., Dietz, J., 2004. R\&D co-operation and innovation activities of firmsevidence for the German manufacturing industry. Research Policy 33, 209-223.

Blanes, J.V., Busom, I., 2004. Who participates in R\&D subsidy programs? The case of Spanish manufacturing firms. Research Policy 33, 1459-1476.

Bozeman, B., 2000. Technology transfer and public policy: a review of research and theory. Research Policy 29, 627-655.

Bozeman, B., Rogers, J., 2001. Strategic management of government-sponsored R\&D portfolios. Environment and Planning C: Government and Policy 19, 413-442.

Cassiman, B., 2000. Research joint ventures and optimal R\&D policy with asymmetric information. International Journal of Industrial Organization 18, 283-314.

Castro, J.C., 2001. Dos años de PROFIT: algunos datos para un balance provisional. Economía Industrial 340, 179-183.

Cozzarin, B., 2008. Data and the measurement of R\&D program impact. Evaluation and Program Planning 31, 284-298.

Das, T., Teng, B., 2000. A resource-based theory of strategic alliances. Journal of Management 26, 31-61.

David, P.A., Hall, B.H., Toole, A.A., 2000. Is public R\&D a complement or substitute for private R\&D? A review of the econometric evidence. Research Policy 29 497-529.

Duysters, G., Kok, G., Vaandrager, M., 1999. Crafting successful strategic technology partnerships. R\&D Management 29 (4), 343-351.

Feller, I., Glasmeier, A., Mark, M., 1996. Issues and perspectives on evaluating manufacturing modernization programs. Research Policy 25, 309-319.

Fölster, S., 1995. Do subsidies to cooperative R\&D actually stimulate R\&D investment and cooperation? Research Policy 24, 403-417.

García-Quevedo, J., 2004. Do public subsidies complement business R\&D? A metaanalysis of the econometric evidence. Kyklos 57, 87-102.

Geroski, P., 1992. Antitrust policy towards co-operative R\&D ventures. Oxford Review of Economic Policy 9, 58-71.

Giebe, T., Grebe, T., Wolfstetter, E., 2006. How to allocate R\&D (and other) subsidies: An experimentally tested policy recommendation. Research Policy 35 (9) $1261-1272$.

Greene, W., 2000. Econometric Analysis, fourth ed. Prentice Hall, Upper Saddle River, N.J.

Hagedoorn, J., Link, A., Vonortas, N., 2000. Research partnerships. Research Policy $29,567-586$

Hamilton, B.H., Nickerson, J.A., 2003. Correcting for endogeneity in strategic management research. Strategic Organization 1 (1), 53-80.

Heijs, J., 2001. Política Tecnológica e Innovación: Evaluación de la Financiación Pública de I+D en España. Consejo Económico y Social de España, Madrid.

Heijs, J., 2003. Freerider behaviour and the public finance of R\&D activities in enterprises: the case of the Spanish low interest credits for R\&D. Research Policy 32 (3), 445-461

Heijs, J., 2005a. Do public policies that foster co-operation in innovation augment the co-operative attitude: The empirical facts. Documentos de trabajo del Instituto de Análisis Industrial y Financiero $\mathrm{N}^{\circ}, 52$

Heijs, J., 2005b. Identification of firms supported by technology policies: the case of Spanish low interest credits. Science and Public Policy 32 (3), 219-230.
Henriksen, A.D., Traynor, A.J., 1999. A practical R\&D project selection scoring tool. IEEE Transactions on Engineering Management 46, 158-170.

Herrera, L., Heijs, J., 2007. Difusión y adicionalidad de las ayudas públicas a la innovación. Revista de Economía Aplicada 44 (15), 177-197.

Hsu, Y.G., Tzeng, G.H., Shyu, J.Z., 2003. Fuzzy multiple criteria selection of government-sponsored frontier technology R\&D projects. R\&D Management 33 (5), 539-551.

Huergo, E., Trenado, M. 2008. Determinantes de la solicitud y concesión de créditos blandos. La empresas española y el apoyo del CDTI a la I+D+i. CDTI Working Paper. Available at http://www.cdti.es/index.asp?MP=35\&MS=0\&MN=1\&TR= C\&IDR= 276\&id Categoria=9\&accion=si.

Klette, T.J., Moen, J., Griliches, Z., 2000. Do subsidies to commercial R\&D reduce market failures? Microeconometric evaluation studies. Research Policy 29, 471-495

Kogut, B., 1988. Joint ventures: Theoretical and empirical perspectives. Strategic Management Journal 9, 312-332.

Lee, M., Om, K., 1996. Different factor considered in project selection at public and private R\&D institutes. Technovation 16 (6), 271-275.

Lee, M., Om, K., 1997. The concept of effectiveness in R\&D project selection. International Journal of Technology Management 13 (5-6), 511-524.

Maddala, G.S., 1983. Limited-Dependent and Qualitative Variables in Econometrics. Cambridge University Press, Cambridge, UK.

Martin, S., 1996. Protection, promotion and cooperation in the European semiconductor industry. Review of Industrial Organization 11, 721-735.

Meyer-Krahmer, F., Montigny, P., 1989. Evaluations of innovation programmes in selected european countries. Research Policy 18, 313-332.

Molas-Gallart, J., Salter, A., 2002. Diversidad y excelencia: Consideraciones sobre política científica. IPTS Report 66.

Molero, J., Buesa, M., 1995. Análisis y evaluación de la actuación del CDTI: resultados preliminares de la explotación de la base de datos del CDTI. Instituto de Análisis Industrial y Financiero.

Nauwelaers, C., Wintjes, R., 2002. Innovating SMEs and regions: The need for policy intelligence and interactive policies. Technology Analysis \& Strategic Management 14 (2), 201-215.

OECD, 2001. OECD Science, Technology and Industry Scoreboard. Towards a knowledge based economy. OECD, París.

Ormala, E., 1989. Nordic experiences of the evaluation of technical research and development. Research Policy 18, 333-342.

Roessner, D., 1989. Evaluating government innovation programmes: lessons from the u.s. experience. Research Policy 18, 343-359.

Shapira, P., Roessner, D., Barke, R., 1995. New public infrastructures for small firm industrial modernization in the USA. Entrepeneurship \& Regional Development 7, 63-84.

Smith, K., 1991. Innovation policy in an evolutionary context. In: Saviotti, P., Metcalfe, S. (Eds.), Evolutionary Theories of Economic and Technological Change. Harwood Academic Publishers, pp. 256-275.

Taggart, J.H., Blaxter, T.J., 1992. Strategy in pharmaceutical R\&D: a portfolio risk matrix. R\&D Management 22 (3), 241-254.

Vence, X., 1998. Industria e innovación. O sistema de innovación e a política tecnolóxica en Galicia. Ed. Xerais. Vigo.

Von Hippel, E., 1988. Sources of Innovation. Oxford University Press, Oxford. 